\title{
Randomized clinical trial to evaluate the effects of a prepartum cholecalciferol injection on postpartum serum calcium dynamics and health and performance in early-lactation multiparous dairy cows
}

\author{
P. L. Venjakob, ${ }^{1} \oplus$ L. Bauerfeind, ${ }^{2}$ R. Staufenbiel, ${ }^{2} \odot$ M. R. Wilkens, ${ }^{3} \odot$ C. Weber, ${ }^{4} \odot$ W. Heuwieser, ${ }^{1 *} \odot$ \\ and S. Borchardt ${ }^{1} \odot$ \\ ${ }^{1}$ Clinic for Animal Reproduction, Faculty of Veterinary Medicine, Freie Universität Berlin, 14163 Berlin, Germany \\ ${ }^{2}$ Ruminant Clinic, Faculty of Veterinary Medicine, Freie Universität Berlin, 14163 Berlin, Germany \\ ${ }^{3}$ Department of Animal Sciences, Animal Nutrition Physiology, University of Goettingen, 37077 Goettingen, Germany \\ ${ }^{4}$ Laboklin GmbH \& Co. KG, Laboratory for Clinical Diagnostics, Steubenstraße 4, 97688 Bad Kissingen, Germany
}

\begin{abstract}
The objectives of the present study were (1) to evaluate the effect of prepartum cholecalciferol treatment on serum Ca concentration during the first $10 \mathrm{~d}$ after calving and (2) to evaluate the effect of treatment on subsequent health and performance. Multiparous Holstein cows $(\mathrm{n}=377)$ from one dairy farm were fed a negative dietary cation-anion difference diet $(-31$ $\mathrm{mEq} / \mathrm{kg}$ of $\mathrm{DM}$ ) for the last $21 \mathrm{~d}$ of gestation. On $\mathrm{d}$ 275 , the animals were randomly assigned to a control or a treatment group. Cows in the control group were left untreated, and cows in the treatment group received an injection of $12 \times 10^{6}$ IU of cholecalciferol intramuscularly on the day of enrollment. If treated cows did not deliver the calf within $6 \mathrm{~d}$, they were reinjected with 10 $\times 10^{6} \mathrm{IU}$ of cholecalciferol. Blood samples were drawn on $1,2,3,5,7$, and 10 days in milk (DIM) and analyzed for serum $\mathrm{Ca}, \mathrm{P}$, and $\mathrm{Mg}$ concentrations. In a subsample of cows (50 control cows, 35 cows treated once with cholecalciferol, and 15 cows treated twice) serum haptoglobin, nonesterified fatty acids, $\beta$-hydroxybutyrate, and 25-hydroxycholecalciferol concentrations were analyzed on 1, 5, and 10 DIM. Binary data [retained placenta (RP), metritis] were analyzed using logistic regression models. Repeated measures ANOVA with first-order autoregressive covariance was performed to evaluate the treatment effect on milk yield over the first 10 test days after parturition, 25-hydroxycholecalciferol, serum Ca, P, Mg, $\beta$-hydroxybutyrate, nonesterified fatty acids, and haptoglobin concentrations. Cox proportional hazards were used to model the time to event outcomes (time to pregnancy within $200 \mathrm{~d}$, culling until 300 DIM). After enrollment of $31.4 \%$ of cows
\end{abstract}

Received April 9, 2021.

Accepted October 16, 2021.

*Corresponding author: w.heuwieser@fu-berlin.de and a preliminary analysis, adverse reactions became apparent, and the study was stopped. Cows treated with cholecalciferol had a greater risk of incurring RP and metritis. The adjusted mean incidences were $2.0 \%$, $7.7 \%$, and $4.0 \%$ for RP, and $21.6 \%, 39.3 \%$, and $33.3 \%$ for metritis for control cows, cows treated once, and cows treated twice with cholecalciferol, respectively. Compared with control cows, cows injected once with $12 \times 10^{6}$ IU of cholecalciferol produced less energy-corrected milk on the first $(-3.76 \mathrm{~kg})$ and second $(-2.75$ $\mathrm{kg})$ test days, respectively. Cows injected twice with cholecalciferol $\left(12 \times 10^{6}\right.$ IU of cholecalciferol and $10 \times$ $10^{6} \mathrm{IU} 1 \mathrm{wk}$ later) had a reduced milk yield only at first test day $(-3.80 \mathrm{~kg})$. Treatment with cholecalciferol led to a significant increase in 25-hydroxycholecalciferol on d 1, 5, and 10 after calving. Serum $\mathrm{Ca}$ and $\mathrm{P}$ concentrations were significantly increased in cows treated with cholecalciferol, but serum $\mathrm{Mg}$ concentrations were significantly reduced. Haptoglobin concentrations were significantly increased on 5 DIM in cows injected once with $12 \times 10^{6}$ IU of cholecalciferol. Although we observed no effect of treatment on culling until 300 DIM, time to pregnancy was delayed by $34 \mathrm{~d}$ in cows injected once with $12 \times 10^{6}$ IU of cholecalciferol. In the present study, injection with $12 \times 10^{6}$ IU of cholecalciferol had detrimental effects on health and milk production despite the beneficial effects on Ca homeostasis.

Key words: vitamin D injection, prevention, hypocalcemia

\section{INTRODUCTION}

The onset of lactation leads to a sudden increase in $\mathrm{Ca}$ requirements due to the loss of $\mathrm{Ca}$ for colostrum and milk production (Goff, 2000). As a result, approximately every second multiparous Holstein cow experiences subclinical hypocalcemia around parturition (Venjakob et al., 2017). Although a transient drop 
of blood Ca concentration might be part of a physiological adaptational response, prolonged hypocalcemia seems to be a risk factor, associated with detrimental effects for DMI, health, and production (McArt and Neves, 2020; Seely et al., 2021; Serrenho et al., 2021b). In the recent past, epidemiological studies have been conducted to evaluate the effect of periparturient hypocalcemia on early-lactation health and performance. Strong evidence exists that hypocalcemic cows have a higher risk for early-lactation diseases (Martinez et al., 2012; Neves et al., 2018; Venjakob et al., 2019), reduced reproductive performance (Martinez et al., 2012; Caixeta et al., 2017; Venjakob et al., 2018), and ultimately a higher culling risk (Seifi et al., 2011; Roberts et al., 2012; Venjakob et al., 2018). One of the reasons for the detrimental effects on the subsequent lactation might be that hypocalcemia impairs neutrophil function (Kimura et al., 2006; Martinez et al., 2012). In the study by Martinez et al. (2012), the phagocytic activity and the capacity for oxidative burst were decreased in neutrophils from cows with subclinical hypocalcemia, compared with normocalcemic cows. Furthermore, the number of neutrophils was significantly reduced in cows with subclinical hypocalcemia.

Decades ago, it was shown that intramuscular injection of cholecalciferol before calving led to an increase in plasma $\mathrm{Ca}$ concentration (Littledike and Horst, 1982). In the liver, cholecalciferol is transformed to 25-hydroxycholecalciferol before it is hydroxylated again in the kidney, leading to the most active form, 1,25-dihydroxycholecalciferol (Horst et al., 2003). To maintain $\mathrm{Ca}$ homeostasis, Ca uptake via the gut is enhanced by 1,25-dihydroxycholecalciferol. It binds to the vitamin $\mathrm{D}$ receptor, a nuclear receptor that acts as a ligand-activated transcription factor. 1,25-Dihydroxycholecalciferol increases gastrointestinal transepithelial Ca transport (Martín-Tereso and Martens, 2014; Wilkens and Muscher-Banse, 2020), probably via trans- and paracellular pathways. In Germany, injection of cholecalciferol 5 to $7 \mathrm{~d}$ before calving has been proposed since the 1970s, to enhance active Ca uptake from the diet before calving (Gürtler et al., 1977). Two different products containing cholecalciferol are approved on the German market. In the summary of product characteristics of both drugs, an injection of 1 $\times 10^{6} \mathrm{IU}$ per $50 \mathrm{~kg}$ of BW and a second injection of $1 \times$ $10^{6} \mathrm{IU}$ of cholecalciferol per $50 \mathrm{~kg}$ of $\mathrm{BW}$ are specified by the manufacturer, if the cow does not calve within 6 d. A dosage of $10 \times 10^{6} \mathrm{IU}$ of cholecalciferol per cow is commonly accepted (Constable et al., 2016; Hodnik et al., 2020, Weber et al., 2021), although Constable et al. (2016) described consistently better results when cows are treated with $1 \times 10^{6} \mathrm{IU}$ per $45 \mathrm{~kg}$ of BW 2 to $8 \mathrm{~d}$ before expected calving date. Moreover, those authors recommend a reinjection with $10 \times 10^{6}$ IU of cholecalciferol, if the calf is not delivered within $10 \mathrm{~d}$ following the first treatment. The dosage recommendation by the manufacturer, however, is extremely high compared with the recommended daily uptake via feed (NRC, 2001) and needs to be critically evaluated. Surprisingly, the effects of cholecalciferol injection on Ca homeostasis and performance in the subsequent lactation have never been evaluated in a randomized controlled trial, although the products are commonly used on German dairy farms (Venjakob et al., 2017).

Results of oral supplementation with vitamin D or its metabolites conflict. Supplementing cows with $15 \mathrm{mg}$ of cholecalciferol or $15 \mathrm{mg}$ of 25-hydroxycholecalciferol at d 6 before calving, Taylor et al. (2008) could not demonstrate an effect on serum Ca homeostasis. On the contrary, Wilkens et al. (2012) found an improved Ca homeostasis from $4 \mathrm{~d}$ before to $4 \mathrm{~d}$ after calving, but only when 25-hydroxyvitamin D supplementation was combined with a negative DCAD diet in the closeup period. Goff et al. (2014a) compared the effect of parathyroid hormone (PTH) injections in cows with a compensated metabolic alkalosis (DCAD +182 mEq/ $\mathrm{kg}$ ) against cows with a compensated metabolic acidosis (DCAD -181 mEq/kg). Conversion to 1,25-dihydroxycholecalciferol was substantially improved in cows that received a negative DCAD diet. Because PTH receptor function is improved in a state of metabolic acidosis, production of 1,25-dihydroxycholecalciferol might be enhanced when cholecalciferol is injected before calving. Moreover, metabolic acidosis leads to increased renal $\mathrm{Ca}$ excretion before calving, thereby increasing 1,25-dihydroxycholecalciferol production and active $\mathrm{Ca}$ transport earlier when feeding of a negative DCAD diet is combined with cholecalciferol injection before calving.

Therefore, the objective of the present study was to evaluate the effect of cholecalciferol treatment in combination with a negative DCAD diet on serum Ca concentration during the first $10 \mathrm{~d}$ after calving and the effect of treatment on subsequent health and performance. Our hypotheses were (1) that treatment with cholecalciferol antepartum increases postpartum Ca concentrations and (2) that treated cows do have lower haptoglobin concentrations until 10 DIM as well as lower body temperature (indicative of inflammation), higher milk production, and improved reproductive performance, and therefore lower culling risk.

\section{MATERIALS AND METHODS}

This randomized controlled study was carried out between June 2019 and November 2020 on a commercial dairy farm in northern Germany. The farm is located in 
the federal state of Brandenburg in northern Germany and has approximately 2,600 milking cows, with an average $305-\mathrm{d}$ milk yield of $9,600 \mathrm{~kg}$. The experimental procedures reported herein were conducted with the approval of the federal authorities (protocol 2347-482019). Sample size was calculated based on results of a previous study in which prevalence of hypocalcemia (serum calcium concentration below $2.0 \mathrm{mmol} / \mathrm{L}$ within $48 \mathrm{~h}$ after calving) was $48 \%$ in multiparous cows (Venjakob et al., 2017). Assuming $80 \%$ power and a confidence level of $95 \%$, a total of 1,200 cows was needed to detect a $16.7 \%$ reduction in prevalence of hypocalcemia. A priori it was planned to conduct a preliminary statistical analysis after enrollment of one-third of the cows. The statistical analysis was conducted when 377 cows were included in the study. Because prepartum application of cholecalciferol to prevent hypocalcemia is approved and common on German dairy farms, criteria for premature termination of the study were not established. However, due to the results of the statistical analysis (i.e., higher disease incidence, reduction in milk yield), the study had to be terminated prematurely to avoid harm to the animals and losses to the farm.

\section{Transition Cow Management}

Cows were dried off at d $223 \pm 10.7$ of gestation. Approximately at d 255 of gestation, cows were moved into the close-up group. Cows were closely monitored for signs of imminent calving. When the amniotic sac or the calf's feet were visible outside the vulva, cows were moved to a maternity pen. At calving, calving ease $(1=$ unassisted calving, $2=$ calving assisted by 1 person, $3=$ calving assisted by more than 1 person), occurrence of stillbirth (alive vs. dead), twins, and calf sex (female vs. male) were recorded. Immediately after birth, all multiparous cows received an oral calcium bolus (Bovikalc, Boehringer Ingelheim) and were moved to the fresh cow pen. Fresh cows were housed in a freestall barn with slatted floors and cubicles equipped with rubber mats for $10 \mathrm{~d}$ after parturition. From d 10 after calving until confirmed pregnancy, cows were housed in a freestall barn with a solid concrete floor and cubicles equipped with manure solids as bedding. Cows were milked 3 times daily in a rotary milking parlor. The farm participated in a federal DHIA equivalent testing system. Results from the 10 test days following parturition were obtained from the on-farm computer system (HerdeW, version 5.8, dsp-Agrosoft Ltd.). Cows were fed a TMR, and feed was delivered via conveyer belt system 2 to 3 times per day. Cows in the close-up group were fed with a negative DCAD diet (DCAD: $-31 \mathrm{mEq} / \mathrm{kg}$; Table 1). Urine $\mathrm{pH}$ was assessed in a subsample of minimum
Table 1. Ingredients and chemical composition (\%, unless otherwise noted) of the close-up diet

\begin{tabular}{lc}
\hline Feed ingredient or nutrient (DM basis) & Proportion \\
\hline Ingredient & \\
Corn silage & 33.60 \\
Grass silage & 54.50 \\
Wheat straw & 3.60 \\
Canola meal & 3.70 \\
Anionic mineral supplement ${ }^{1}$ & 4.60 \\
Nutrient composition & \\
CP & 13.50 \\
NDF & 48.80 \\
NFC & \\
Starch & 14.30 \\
Ash & 8.50 \\
Calcium & 0.94 \\
Phosphorus & 0.33 \\
Magnesium & 0.35 \\
Sodium $_{\text {Potassium }}$ & 0.36 \\
Chloride & 1.78 \\
Sulfur $_{\text {NE }}(\mathrm{MJ} / \mathrm{kg})$ & 1.32 \\
DCAD $^{3}(\mathrm{mEq} / \mathrm{kg})$ & 0.40 \\
\hline
\end{tabular}

${ }^{1}$ Transifit (Dr. Pieper Technologie- und Produktentwicklung GmbH): $8.1 \% \mathrm{~S} ; 4.0 \% \mathrm{Mg} ; 2.9 \% \mathrm{Na} ; 2.5 \% \mathrm{P} ; 20.0 \% \mathrm{Ca} ; 35,000 \mathrm{IU}$ of cholecalciferol $/ \mathrm{kg}$.

${ }^{2}$ Calculated as: $100-\mathrm{CP}-\mathrm{NDF}-$ ash.

${ }^{3} \mathrm{DCAD}=[(\mathrm{Na} \%$ of $\mathrm{DM} / 0.023)+(\mathrm{K} \%$ of DM/0.039) $]-[(\mathrm{S} \%$ of $\mathrm{DM} / 0.016)+(\mathrm{Cl} \%$ of $\mathrm{DM} / 0.0355)]$.

10 cows per week in the close-up group. During the study period, the average urine $\mathrm{pH}$ was $6.8( \pm 0.98 ; \mathrm{n}=$ 122). The TMR sample from the close-up diet was analyzed in a commercial laboratory (Landwirtschaftliche Kommunikations- und Servicegesellschaft mbH, Lichtenwalde, Germany). The TMR was balanced to meet or exceed minimum nutritional requirements for dairy cows (NRC, 2001) containing 2,000 IU of cholecalciferol per kilogram of DM.

\section{Treatment Allocation}

Multiparous cows were enrolled on d 275 of gestation and randomly assigned to a control $(\mathrm{n}=187)$ or a treatment $(\mathrm{n}=190)$ group, based on the last digit of their unique 10-digit animal identification number. Odd-numbered cows were assigned to the treatment group, and even-numbered cows were assigned to the control group. Cows of the control group were left untreated, and cows in the treatment group received an injection of $12 \times 10^{6}$ IU of cholecalciferol intramuscularly on the day of enrollment (Ursovit $\mathrm{D}_{3}$, Serumwerk Bernburg), according to the prescription label. Cows were reinjected with $10 \times 10^{6} \mathrm{IU}$ of cholecalciferol if they did not deliver the calf during the week following the first injection. Researchers were not blinded to the treatment allocation. 


\section{Diagnosis of Diseases}

During the first $10 \mathrm{~d}$ after calving, cows were examined daily following standard operating protocols created by the herd manager. During examination, rectal temperature was measured using a commercial thermometer (Veterinär-Thermometer SC 12, Scala Electronic $\mathrm{GmbH}$ ), and cows were monitored visually to assess general appearance, presence of fetal membranes outside the vulva, vaginal discharge, lameness, udder health, and manure consistency. Blood ketone concentration was evaluated once a week using a hand-held electronic ketone meter, beginning at 2 DIM (TaiDoc, Pharmadoc). Cows were diagnosed with retained placenta (RP) when fetal membranes were not expelled within $24 \mathrm{~h}$ after parturition. Vaginal discharge was evaluated on $\mathrm{d} 7$ after calving using a Metricheck device (Simcro). Based on the scoring system used by Urton et al. (2005) no mucus or clear mucus was categorized as score 0 , cloudy mucus or mucus with flecks of pus as score 1 , mucopurulent ( $\leq 50 \%$ pus present) and foul smelling as score 2 ; purulent ( $\geq 50 \%$ pus present) and foul smelling as score 3, and putrid (red or brown color, watery, foul smelling) was categorized as score 4 . Cows with score 4 were considered as having metritis (Sheldon et al., 2006).

\section{Blood Sampling and Analyses}

Cows enrolled in this study were restrained in headlocks at $0800 \mathrm{~h}$ every morning. The first blood sample (d 1) was collected within $24 \mathrm{~h}$ after calving. Further blood samples were drawn on d 2, 3, 5, 7, and 10 after calving. All blood samples were obtained from the coccygeal vessels using a serum blood collection system comprising a sterile needle (Sterican, $1.20 \times 40 \mathrm{~mm}$, B. Braun Melsungen AG) and a tube without anticoagulants (Monovette $9 \mathrm{~mL} \mathrm{Z}$, Sarstedt AG \& Co.). Blood samples were kept at room temperature for about 30 min to clot. Subsequently, samples were centrifuged at approximately $20^{\circ} \mathrm{C}$ and $2,000 \times g$ for 20 min to harvest serum (Heraeus Sepatech Labofuge 200, Heraeus Holding $\mathrm{GmbH}$ ). Serum was transferred into $5-\mathrm{mL}$ tubes (5 mL Röhrchen, Sarstedt AG \& Co.), using a pipette (Transferpipette $3.5 \mathrm{~mL}$, Sarstedt AG \& Co.) and frozen at $-20^{\circ} \mathrm{C}$. Serum concentrations of $\mathrm{Ca}, \mathrm{Mg}$, and $\mathrm{P}$ were measured in the laboratory of the Ruminant Clinic, Freie Universität Berlin. Total serum Ca concentration, serum inorganic $\mathrm{P}$ concentration, and serum $\mathrm{Mg}$ concentration were analyzed using a Cobas 8000 c701 (Roche Diagnostics International AG) and test kits LT-Ca 0100, LT-P 0100, and LT-MG 0103, respectively (Labor + Technik Eberhard Lehmann GmbH). The interassay coefficients of variation were $4.15 \%$ (Ca
$=2.17 \mathrm{mmol} / \mathrm{L} ; \mathrm{n}=30), 3.24 \%(\mathrm{P}=1.74 \mathrm{mmol} / \mathrm{L} ; \mathrm{n}$ $=30), 7.51 \%(\mathrm{Mg}=0.88 \mathrm{mmol} / \mathrm{L} ; \mathrm{n}=23)$. The intraassay coefficients of variation were $2.57 \%(\mathrm{Ca}=2.17$ $\mathrm{mmol} / \mathrm{L} ; \mathrm{n}=30), 2.10 \%(\mathrm{P}=1.74 \mathrm{mmol} / \mathrm{L} ; \mathrm{n}=30)$, and $2.85 \%(\mathrm{Mg}=0.88 \mathrm{mmol} / \mathrm{L} ; \mathrm{n}=23)$. Haptoglobin, BHB, nonesterified fatty acids (NEFA), and 25-hydroxycholecalciferol were analyzed by a commercial laboratory (Laboklin GmbH \& Co. KG, Laboratory for Clinical Diagnostics, Bad Kissingen, Germany). Serum haptoglobin concentrations were determined by photometric methods using a phase haptoglobin assay test kit (Tridelta Development Ltd.). Evaluation of serum NEFA concentrations was conducted by photometry using a NEFA test kit (Randox). Evaluation of serum BHB concentrations was conducted by enzymatickinetic methods using a Ranbut test kit (Randox). Serum haptoglobin, NEFA, and BHB concentrations were measured using a Cobas 8000 c701 (Roche Diagnostics International AG). Serum 25-hydroxycholecalciferol was determined via chemiluminescence immunoassay using an ADVIA Centaur VitD test kit and ADVIA Centaur XPT (Siemens). The interassay coefficients of variation were $3.7 \%(1.27 \mathrm{~g} / \mathrm{L} ; \mathrm{n}=5)$ and $4.76 \%(0.21$ $\mathrm{mmol} / \mathrm{L} ; \mathrm{n}=5$ ) for haptoglobin and BHB concentrations, respectively. Interassay coefficients of variation were and $1.50 \%(0.99 \mathrm{mmol} / \mathrm{L} ; \mathrm{n}=5)$ and $3.81 \%(1.40$ $\mathrm{mmol} / \mathrm{L} ; \mathrm{n}=5$ ) for NEFA. For 25-hydroxycholecalciferol the interassay coefficients of variation were $12.12 \%$ (53.74 nmol/l; $\mathrm{n}=5)$ and $2.91 \%(218.71 \mathrm{nmol} / \mathrm{l} ; \mathrm{n}=$ $5)$. The intraassay coefficients of variation were $0.4 \%$ $(1.21 \mathrm{~g} / \mathrm{L} ; \mathrm{n}=5)$ and $2.10 \%(0.21 \mathrm{mmol} / \mathrm{L} ; \mathrm{n}=5)$ for haptoglobin and BHB concentrations, respectively. The intraassay coefficients of variation for NEFA were $1.75 \%(0.99 \mathrm{mmol} / \mathrm{L} ; \mathrm{n}=5)$ and $1.24(1.53 \mathrm{mmol} / \mathrm{L} ; \mathrm{n}$ $=5)$. For 25 -hydroxycholecalciferol the intraassay coefficients of variation were $8.35 \%(59.61 \mathrm{nmol} / \mathrm{l} ; \mathrm{n}=5)$ and $2.72 \%(212.38 \mathrm{nmol} / \mathrm{l}, \mathrm{n}=5)$. All validations were conducted according to CLSI (2012) guidelines.

\section{Reproductive Management}

Voluntary waiting period was set at 50 DIM. Estrus detection was based on visual observation conducted 3 times per day for $30 \mathrm{~min}$ in the barn by a single professional AI technician. All cows not detected in estrus until 90 DIM were enrolled into a timed AI protocol [Ovsynch-56: GnRH (100 $\mu \mathrm{g}$ of Gonadorelin, Gonavet Veyx, Veyx Pharma Ltd.) at 90 DIM, PGF2 $\alpha$ (500 $\mu \mathrm{g}$ of Cloprostenol, PGF Veyx forte, Veyx Pharma Ltd.) 7 d later, GnRH $56 \mathrm{~h}$ after PGF2 $\alpha$, and TAI 12 to $16 \mathrm{~h}$ later]. A single professional AI technician performed all inseminations. Pregnancy status was evaluated using transrectal palpation by the AI technician around 40 d after AI. Breeding information (i.e., cow ID, calving 
date, lactation number, breeding date) and results of pregnancy diagnoses were also obtained from the onfarm computer system.

\section{Statistical Analyses}

Results from blood analysis, breeding information, and test day data were combined using Access (Office 2010, Microsoft Deutschland Ltd.), exported to Excel spreadsheets (Office 2010), and analyzed using SPSS for Windows (version 25.0, IBM Corp.).

Repeated measures ANOVA with first-order autoregressive covariance was performed using the GENLINMIXED procedure of SPSS. Nine different models were calculated to evaluate the effects of prepartum cholecalciferol injection on serum $\mathrm{Ca}, \mathrm{P}, \mathrm{Mg}, \mathrm{BHB}, \mathrm{NEFA}$, haptoglobin, 25-hydroxycholecalciferol concentration, rectal temperature, and milk yield over the first 10 test days after parturition. For the models of $\mathrm{Ca}, \mathrm{P}$, and $\mathrm{Mg}$ repeated measures were conducted on d 1, 2, 3, 5, 7, and 10 after calving. For the models of BHB, NEFA, haptoglobin, and 25-hydroxycholecalciferol, repeated measures were conducted on d 1, 5, and 10 after calving. For evaluation of rectal temperature, repeated measures were conducted on d 1,2,3,5, and 7 after calving. Cow was the experimental unit. According to the model-building strategies described by (Dohoo et al., 2009), each parameter considered for the mixed model was separately analyzed in a univariable model. Only parameters resulting in univariable models with $P$ $\leq 0.10$ were included in the final mixed model. Selection of the model that best fit the data was performed by using a backward stepwise elimination procedure that removed all variables with $P>0.10$ from the model. The initial models contained the following fixed effects: parity (lactation 2, 3, and $\geq 4$ ), time (blood samples on d 1, 2, 3, 5, 7, and 10 for $\mathrm{Ca}, \mathrm{Mg}$, and P models; blood samples on d 1, 5, and 10 for 25-hydroxycholecalciferol, BHB, NEFA, and haptoglobin models; temperature measured on $\mathrm{d} 1,2,3,5$, and 7 for the model of rectal temperature; milk yield on test d 1 to 10 for the model of milk yield), treatment (cows treated once vs. cows treated twice with cholecalciferol vs. no treatment), calving ease $(0=$ no assistance, $1=$ calving assisted by 1 person, 2 = calving assisted by 2 people, $3=$ calving assisted by more than 2 people; categorical), stillbirth (yes vs. no), twins (yes vs. no), sex of the calf (male vs. female), 305-d milk yield in previous lactation (continuous), and gestation length (GL; continuous). Furthermore, serum Ca concentration on d 1 was included in the model of 25-hydroxycholecalciferol. We tested all plausible biological interactions such as time by treatment and time by treatment by parity. Regardless of the significance level, treatment and the interaction of time and treatment were forced to remain in the model.

To further evaluate the effect of treatment on probability of RP and metritis, 2 separate logistic regression models were built, using the GENLINMIXED procedure of SPSS. Except for time, we included the same variables as fixed effects, as for the models described above. Regardless of the significance level, treatment was forced to remain in the model.

Cox proportional hazard models were used to model the time to event outcomes (i.e., culling within 300 DIM, time to pregnancy within 200 DIM). Cows were censored if they were not pregnant or culled or at the end of the observation period. The variables parity, treatment, and previous 305-d milk yield were tested as risk factors. Models with the most extreme $\beta$-value for treatment and the lowest $P$-value were selected. Proportional hazards assumption was graphically assessed by plotting the $-\ln [-\ln$ (survival)] curves for cows in the control group and cows in the treatment group against the $\ln$ (survival time). Proportional hazards assumption was assumed to be met when the lines were approximately parallel.

\section{RESULTS}

Deviating from the original study protocol with an inclusion of 1,200 cows, the study had to be stopped after enrollment of 377 cows, due to detrimental effects on early-lactation health and production caused by the cholecalciferol treatment. Of those 377 cows, 188 and 189 were control and treated cows, respectively. Due to adverse reactions (i.e., dyspnea, urticaria) in association with the cholecalciferol injection, 2 cows had to be excluded from the study. In the group of treated cows, 54 cows were reinjected with $10 \times 10^{6}$ IU of cholecalciferol, as they did not deliver the calf within $6 \mathrm{~d}$ after the first treatment. Of the remaining 375 animals, 132 $(35.2 \%), 110(29.3 \%)$, and $133(35.5 \%)$ were in second, third, and fourth or greater lactation, respectively. Mean parity was $2.98 \pm 0.06,3.03 \pm 0.07$, and $3.00 \pm$ 0.12 for cows in the control group, cows treated once, and cows treated twice with cholecalciferol, respectively $(P=0.856)$. Mean calving ease was $1.15 \pm 0.34,1.24$ \pm 0.40 , and $1.17 \pm 0.64$ for cows in the control group, cows treated once, and cows treated twice with cholecalciferol, respectively $(P=0.191)$. Gestation length at enrollment was $275.4 \pm 0.13,275.2 \pm 0.16$, and $274.7 \pm$ $0.25 \mathrm{~d}$ for cows in the control group, cows treated once, and cows treated twice with cholecalciferol, respectively $(P=0.073)$. Gestation length was $281.3 \pm 0.24,278.5$ \pm 0.28 , and $284.7 \pm 0.44 \mathrm{~d}$ for cows in the control group, cows treated once, and cows treated twice with 
cholecalciferol, respectively $(P<0.001)$. Interval from enrollment to calving was $6.0 \pm 0.23,3.3 \pm 0.27$, and $10.0 \pm 0.43 \mathrm{~d}$ for cows in the control group, cows treated once, and cows treated twice with cholecalciferol, respectively $(P<0.001)$. During the study period, $5.9 \%$ $(22 / 375)$ of cows developed RP. Metritis affected $14.4 \%$ (54/375) of cows.

Treatment with cholecalciferol before calving affected serum Ca dynamics within the first 10 DIM. Whereas cows with an injection of $12 \times 10^{6}$ IU of cholecalciferol $5 \mathrm{~d}$ before calving had significantly higher serum Ca concentrations than control cows, cows with 2 injections of cholecalciferol at a 1-wk interval had significantly greater serum $\mathrm{Ca}$ concentrations than cows with a single injection and control cows (Figure 1A; mean Ca concentrations were $1.81 \mathrm{mmol} / \mathrm{L}, 2.02$ $\mathrm{mmol} / \mathrm{L}$, and $2.18 \mathrm{mmol} / \mathrm{L}$ for control cows and cows treated once or twice with cholecalciferol, respectively; $P<0.001)$. A similar effect was observed for serum $\mathrm{P}$ dynamics. Mean serum $\mathrm{P}$ concentrations were 1.42 $\mathrm{mmol} / \mathrm{L}, 1.86 \mathrm{mmol} / \mathrm{L}$, and $2.05 \mathrm{mmol} / \mathrm{L}$ for control cows and cows treated once or twice with cholecalciferol, respectively (Figure 1B; $P<0.001$ ). Cows treated with cholecalciferol had significantly reduced serum $\mathrm{Mg}$ concentrations. No difference was detectable, however, between cows treated once or twice with cholecalciferol (Figure 1C; mean serum $\mathrm{Mg}$ concentrations were 0.77 $\mathrm{mmol} / \mathrm{L}, 0.67 \mathrm{mmol} / \mathrm{L}$, and $0.66 \mathrm{mmol} / \mathrm{L}$ for control cows and cows treated once or twice with cholecalciferol, respectively; $P<0.001$ ).

In a subsample of cows $(50,35$, and 15 for control cows and cows treated once or twice with cholecalciferol, respectively), 25-hydroxycholecalciferol, BHB, NEFA, and haptoglobin levels were determined on d 1 , 5, and 10 after calving. Treated cows had considerably increased concentrations of 25-hydroxycholecalciferol (Figure 2; mean 25-hydroxycholecalciferol concentrations were $42.8 \mathrm{nmol} / \mathrm{L}, 227.4 \mathrm{nmol} / \mathrm{L}$, and 309.7 $\mathrm{nmol} / \mathrm{L}$ for control cows and cows treated once or twice with cholecalciferol, respectively; $P<0.001)$. The difference was most pronounced on d 1 after calving but remained significantly higher on d 5 and 10. Although treatment had no effect on serum BHB (Figure 3A; $P=0.394$ ) and serum NEFA concentrations (Figure 3B; $P=0.104$ ) on $\mathrm{d} 1,5$, and 10 after calving, serum haptoglobin concentrations on $\mathrm{d} 5$ were increased for cows treated once with $12 \times 10^{6}$ IU of cholecalciferol $5 \mathrm{~d}$ before calving compared with control cows (Figure $3 \mathrm{C} ; P=0.005)$. Mean haptoglobin concentrations on $\mathrm{d}$ 5 were $0.68 \mathrm{~g} / \mathrm{L}$ and $1.11 \mathrm{~g} / \mathrm{L}$ for control cows and cows treated once, respectively $(P=0.002)$. The haptoglobin concentration of cows treated twice was not statistically different from control cows $(P=0.379)$ and cows treated once $(P=0.149)$. Cows treated once with chole- calciferol had a greater risk of incurring $\mathrm{RP}$ (odds ratio $=4.15 ; P=0.036$; Table 2). Cows with 2 injections of cholecalciferol in a 1-wk interval, however, did not have a higher risk for RP compared with control cows $(P=$ $0.314)$. The adjusted mean incidences of RP were $2.0 \%$, $7.7 \%$, and $4.0 \%$ for control cows, cows treated once, and cows treated twice with cholecalciferol. Cows that were treated once with cholecalciferol (odds ratio $=$ 2.35; $P<0.001$; Table 3) and cows treated twice with cholecalciferol (odds ratio $=1.82 ; P=0.002$; Table 3 ) had increased odds for metritis compared with control cows. Adjusted mean incidences for metritis were $21.6 \%, 39.3 \%$, and $33.3 \%$ for control cows, cows treated once, and cows treated twice with cholecalciferol. Evaluating the effect of cholecalciferol treatment on rectal temperature, a tendency for a 3 -way interaction of time by treatment by parity was observed $(P=0.064)$, indicating a treatment effect on rectal temperature that depended on parity. Whereas in second-lactation cows, rectal temperature of cows treated once with cholecalciferol was lower compared with control cows on d 2 after calving $(P=0.011)$, cows in fourth lactation or greater treated twice with cholecalciferol had a higher rectal temperature on d $2(P=0.019)$ compared with control cows. Moreover, in second-lactation cows, rectal temperature of cows treated once with cholecalciferol was significantly higher than rectal temperature of cows treated twice with cholecalciferol on d 7 after calving $(P=0.031)$.

Cows treated with cholecalciferol before parturition had significantly lower ECM at first test day (mean DIM at first test $=21.3$; range 6 to 49 DIM), compared with cows from the control group. Mean ECM at first test day was $42.5 \mathrm{~kg}, 38.8 \mathrm{~kg}$, and $38.7 \mathrm{~kg}$ for control cows and cows treated once or twice with cholecalciferol, respectively (control vs. 1 injection, $P=0.001$; control vs. 2 injections, $P=0.014$ ). Compared with control cows, on the second test day, milk yield remained lower only in cows treated once with cholecalciferol $(45.3 \mathrm{~kg}$ vs. $42.5 \mathrm{~kg}, P=0.001$; mean DIM at second test $=$ 51.3 ; range 34 to $68 \mathrm{DIM})$. No difference in milk yield was observed from 3rd to 10th DHIA equivalent test.

Cows treated once with $12 \times 10^{6}$ IU of cholecalciferol $5 \mathrm{~d}$ before calving had a significantly reduced hazard of pregnancy within 200 DIM compared with control cows (hazard ratio $=0.70 ; 95 \%$ CI: $0.52-0.95 ; P=0.020$ ). Median times to pregnancy were $146 \mathrm{~d}$ and $180 \mathrm{~d}$ for control cows and cows treated once with cholecalciferol, respectively. Cows treated twice with cholecalciferol did not have a significantly reduced hazard of pregnancy within 200 DIM $(P=0.484$; median time to pregnancy $=154 \mathrm{~d}$ ).

Of the 375 cows enrolled, 98 (26.1\%) cows were culled before 300 DIM. Prepartum treatment with cholecalcif- 

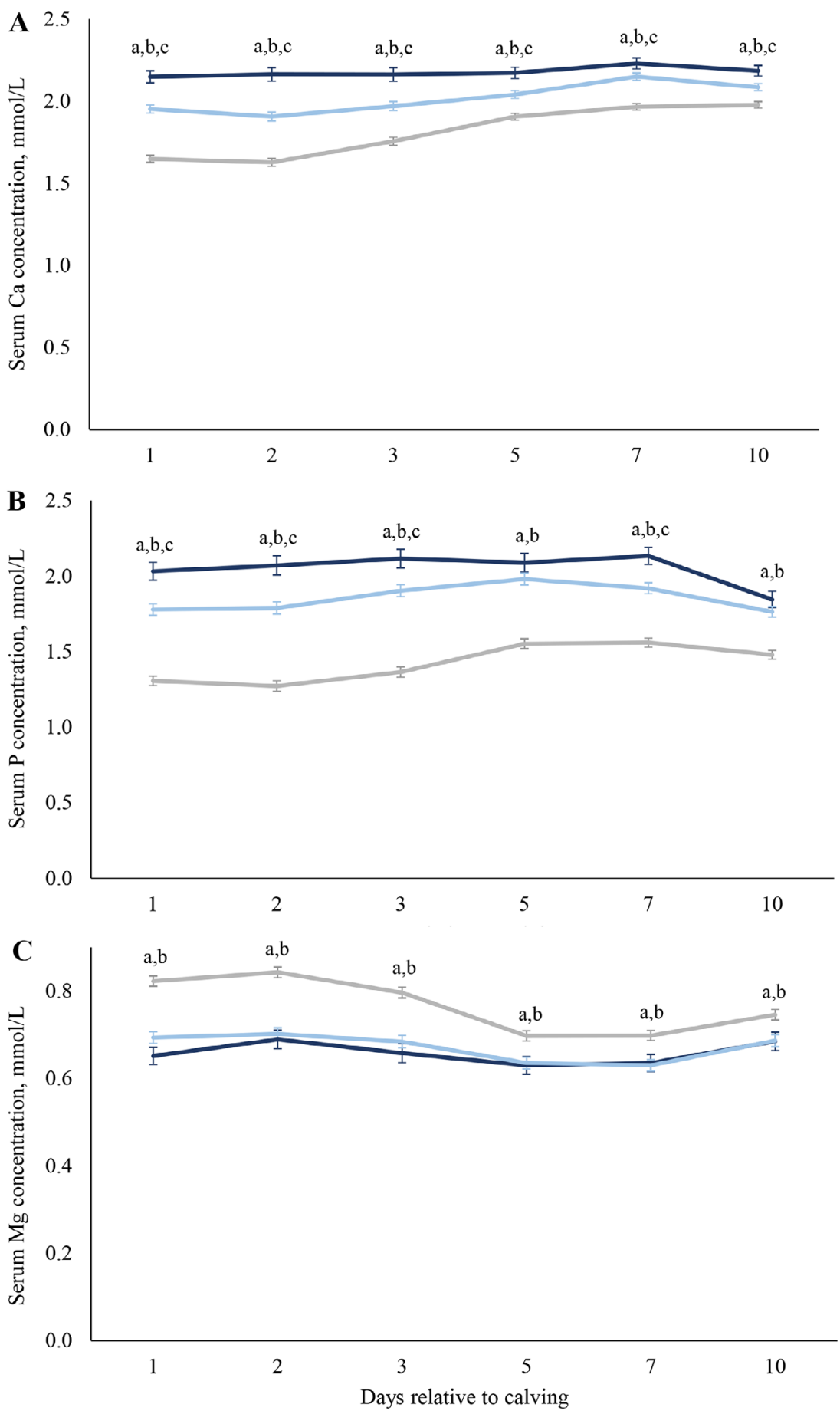

Figure 1. Effects of treatment with $12 \times 10^{6} \mathrm{IU}$ of cholecalciferol $5 \mathrm{~d}$ before expected parturition on serum Ca (panel A), P (panel B), and $\mathrm{Mg}$ (panel $\mathrm{C}$ ) concentrations $(\mathrm{mmol} / \mathrm{L})$ in multiparous dairy cows $(\mathrm{n}=375)$ using least square estimates $($ mean $\pm \mathrm{SEM})$ from repeated measure ANOVA. Cows were reinjected with $10 \times 10^{6} \mathrm{IU}$ of cholecalciferol if they did not deliver the calf within $6 \mathrm{~d}$ after the first treatment. Cows treated with a single cholecalciferol injection are displayed in light blue $(\mathrm{n}=133)$, cows with 2 cholecalciferol injections are displayed in black $(\mathrm{n}=54)$, and cows of the control group $(\mathrm{n}=188)$ are displayed in gray. In panel $\mathrm{A}$, parity $(P<0.001)$, time $(P<0.001)$, treatment $(P<0.001)$, time by treatment $(P<0.001)$, and 305-d milk yield of previous lactation $(P=0.007)$ had a significant effect on serum Ca concentration. We found a tendency for sex of the calf $(P=0.064)$ and calving ease $(P=0.080)$ to be associated with serum Ca concentration. In panel B, parity $(P<$ $0.001)$, time $(P<0.001)$, treatment $(P<0.001)$, and time by treatment $(P<0.001)$ had a significant effect on serum $\mathrm{P}$ concentration. In panel C, parity $(P<0.001)$, time $(P<0.001)$, treatment $(P<0.001)$, time by treatment $(P<0.001)$, calving ease $(P<0.001)$, and gestation length $(P=0.008)$ had a significant effect on serum $\mathrm{Mg}$ concentration. Pairwise comparisons among groups with Bonferroni's corrected $P<0.05$ are marked with the following letters: a, control vs. single injection of cholecalciferol; b, control vs. 2 injections of cholecalciferol; c, single injection of cholecalciferol vs. 2 injections of cholecalciferol. 


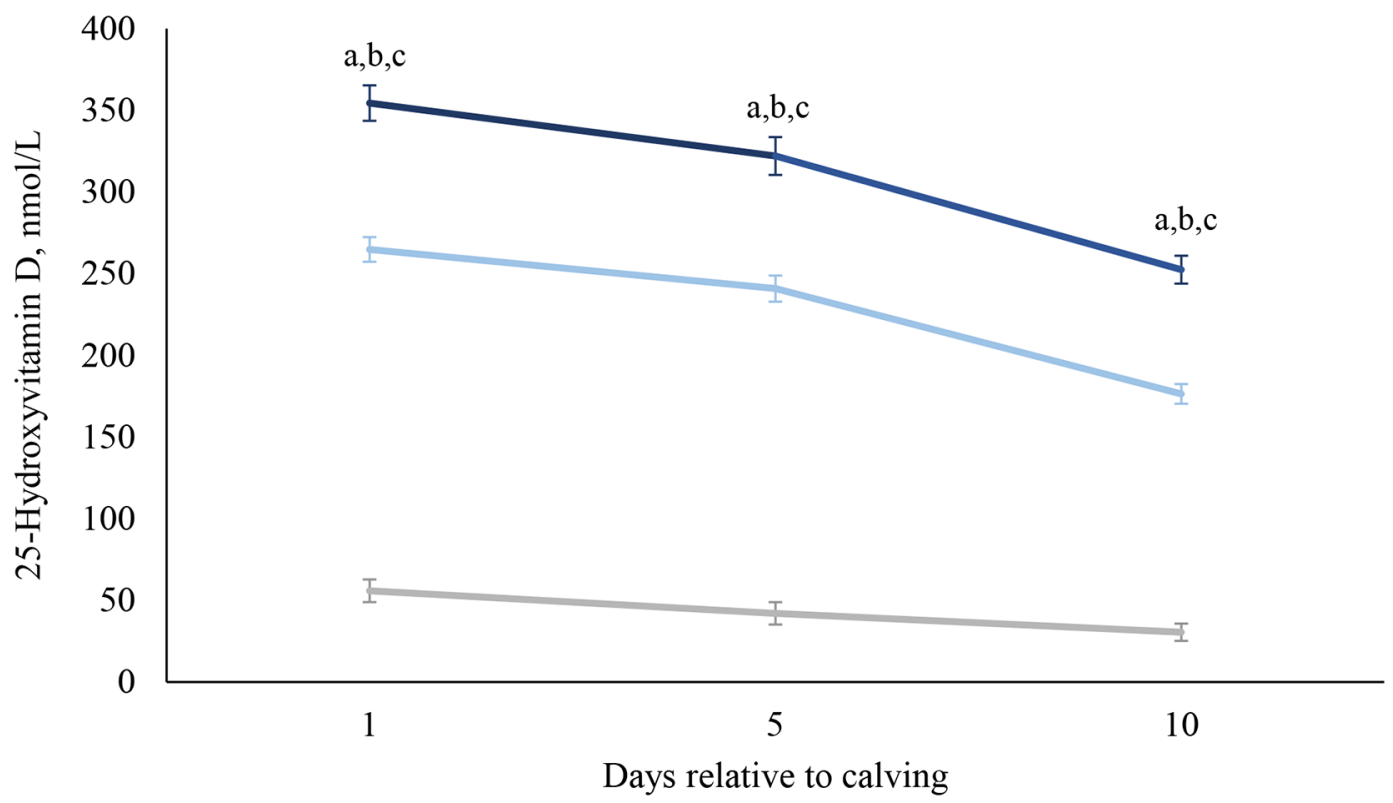

Figure 2. Effect of treatment with $12 \times 10^{6} \mathrm{IU}$ of cholecalciferol $5 \mathrm{~d}$ before expected parturition on logarithmic concentration of vitamin $\mathrm{D}(\mathrm{nmol} / \mathrm{L})$ in multiparous dairy cows $(\mathrm{n}=100)$ using least square estimates (mean \pm SEM) from repeated measure ANOVA. Cows were reinjected with $10 \times 10^{6} \mathrm{IU}$ of cholecalciferol if they did not deliver the calf within $6 \mathrm{~d}$ after the first treatment. Cows treated once with cholecalciferol are displayed in light blue $(\mathrm{n}=35)$, cows treated with cholecalciferol twice are displayed in black $(\mathrm{n}=15)$, and cows of the control group $(\mathrm{n}=50)$ are displayed in gray. Parity $(P=0.012)$, time $(P<0.001)$, treatment $(P<0.001)$, time by treatment $(P<0.001)$, serum Ca concentration at d $1(P<0.001)$, and calving ease $(P=0.016)$ had a significant effect on 25 -hydroxycholecalciferol concentrations after calving. Pairwise comparisons among groups with Bonferroni's corrected $P<0.05$ are marked with the following letters: a, control vs. single injection of cholecalciferol; b, control vs. 2 injections of cholecalciferol; c, single injection of cholecalciferol vs. 2 injections of cholecalciferol.

erol had no effect on the risk of being culled before $300 \operatorname{DIM}(P=0.946)$. Fifty-six of the culled cows were slaughtered before 300 DIM. Of those, $14.4 \%, 17.3 \%$, and $11.1 \%$ were control cows, cows treated once, and cows treated twice with cholecalciferol, respectively. Furthermore, 42 of the culled animals died or were euthanized before 300 DIM. Of those, $12.2 \%, 8.3 \%$, and $12.9 \%$ were control cows, cows treated once, and cows treated twice with cholecalciferol, respectively.

\section{DISCUSSION}

The study was stopped after a preliminary statistical analysis, as treatment with cholecalciferol had detrimental effects on health and milk production despite beneficial effects on $\mathrm{Ca}$ homeostasis. In multiparous cows, treatment with cholecalciferol increased serum Ca concentrations from d 1 to d 10 after calving (Figure $1 \mathrm{~A}$ ). Although cows treated with $12 \times 10^{6} \mathrm{IU}$ of cholecalciferol had greater serum $\mathrm{Ca}$ concentrations than control cows, cows reinjected with $10 \times 10^{6} \mathrm{IU}$ of cholecalciferol $6 \mathrm{~d}$ after the first treatment had greater serum Ca concentrations than control cows and cows treated once. It has already been shown in the early 1980s that application of cholecalciferol led to an increase in plasma Ca concentration on d 1 after calving
(Littledike and Horst, 1982). Mean Ca concentration of cows treated with cholecalciferol was $2.2 \mathrm{mmol} / \mathrm{L} \mathrm{com-}$ pared with $1.38 \mathrm{mmol} / \mathrm{L}$ in control cows in the study by Littledike and Horst (1982). In their study, however, cows were treated with $15 \times 10^{6} \mathrm{IU}$ of cholecalciferol approximately 1 mo before calving followed by a treatment with $2.5 \times 10^{6}$ IU of cholecalciferol 1 wk later. In another study, using a similar study design to ours, cows were treated with $10 \times 10^{6} \mathrm{IU}$ of cholecalciferol $7 \mathrm{~d}$ before expected calving, and treatment with the same amount of cholecalciferol was only repeated when a cow did not deliver the calf within the following $7 \mathrm{~d}$. The authors showed that cholecalciferol was beneficial in cows with milk fever in previous lactations, as the incidence of clinical milk fever was reduced (Julien et al., 1977).

Serum $\mathrm{P}$ dynamics were comparable to serum Ca dynamics. Throughout the sampling period, serum $\mathrm{P}$ concentrations were significantly higher in cows treated with cholecalciferol (Figure 1B). As shown by Wilkens et al. (2012) feeding of 25-hydroxycholecalciferol led to an increase of plasma ionized $\mathrm{P}$ around parturition. Oehlschlaeger et al. (2014) further demonstrated that gastrointestinal $\mathrm{P}$ absorption was increased in cows fed with a negative DCAD diet and 25-hydroxycholecalciferol. 

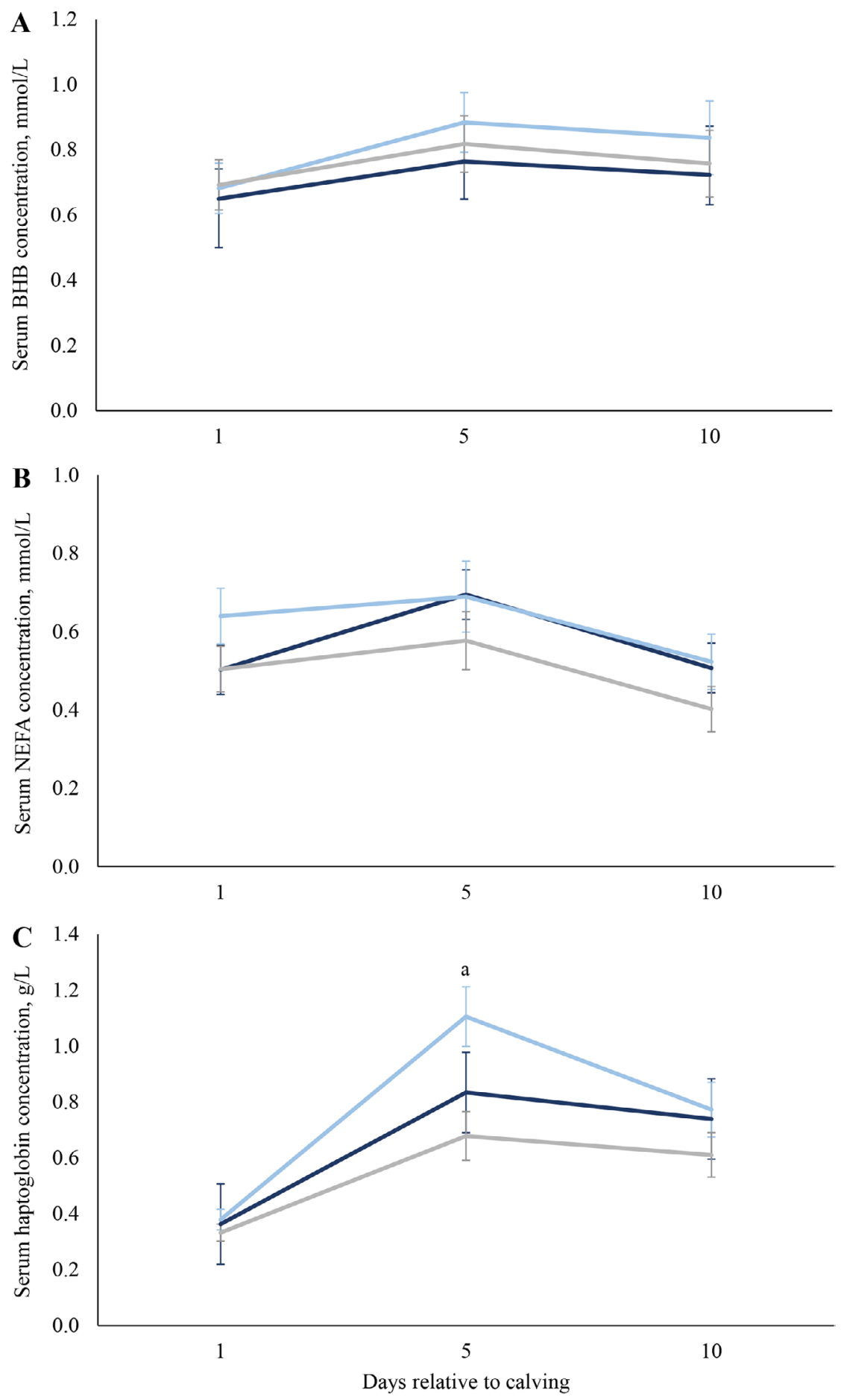

Figure 3. Effect of treatment with $12 \times 10^{6} \mathrm{IU}$ of cholecalciferol $5 \mathrm{~d}$ before expected parturition on serum BHB (panel A), nonesterified fatty acids (NEFA, panel B), and haptoglobin (panel C) concentrations $(\mathrm{mmol} / \mathrm{L})$ in multiparous dairy cows $(\mathrm{n}=100)$ using least square estimates (mean \pm SEM) from repeated measure ANOVA. Cows were reinjected with $10 \times 10^{6}$ IU of cholecalciferol if they did not deliver the calf within 6 $\mathrm{d}$ after the first treatment. Cows treated once with cholecalciferol are displayed in light blue $(\mathrm{n}=35)$, cows treated twice with cholecalciferol are displayed in black $(\mathrm{n}=15)$, and cows of the control group $(\mathrm{n}=50)$ are displayed in gray. Whereas in panel A treatment and time by treatment did not have a significant effect, time $(P=0.002)$ and birth of twins $(P=0.009)$ were significantly associated with serum BHB concentration. We found a tendency for parity $(P=0.082)$, calving ease $(P=0.081)$, and stillbirth $(P=0.065)$ to affect serum BHB concentration significantly. In panel $\mathrm{B}$, treatment and time by treatment did not have a significant effect. Although parity $(P<0.001)$ had a significant effect on serum NEFA concentrations, a tendency for time $(P=0.060)$ to influence serum NEFA concentration was observed. In panel C, parity $(P=0.030)$, time $(P<0.001)$, and treatment $(P=0.005)$ were significantly associated with serum haptoglobin concentration. Pairwise comparisons among groups with Bonferroni's corrected $P<0.05$ are marked with letter a (control vs. single injection of cholecalciferol). 
Table 2. Final multivariable logistic regression model evaluating the effect of prepartum injection with cholecalciferol on the probability of retained placenta ${ }^{1}$

\begin{tabular}{|c|c|c|c|c|c|c|}
\hline \multirow[b]{2}{*}{ Variable } & \multirow[b]{2}{*}{ Estimate } & \multirow[b]{2}{*}{$\mathrm{SE}$} & \multicolumn{2}{|c|}{$95 \% \mathrm{CI}$} & \multirow[b]{2}{*}{ Odds ratio } & \multirow[b]{2}{*}{$P$-value } \\
\hline & & & Lower CI & Upper CI & & \\
\hline Intercept & -4.57 & 0.60 & -6.24 & -2.89 & 0.01 & 0.002 \\
\hline \multicolumn{7}{|l|}{ Parity } \\
\hline 2 & Referent & & & & & \\
\hline 3 & 0.21 & 0.70 & -1.74 & 2.16 & 1.23 & 0.780 \\
\hline$\geq 4$ & 1.76 & 0.55 & 0.24 & 3.28 & 5.80 & 0.033 \\
\hline \multicolumn{7}{|l|}{ Treatment } \\
\hline Control & Referent & & & & & \\
\hline Treatment $^{2}$ & 1.42 & 0.46 & 0.15 & 2.70 & 4.15 & 0.036 \\
\hline Second treatment ${ }^{3}$ & 0.74 & 0.64 & -1.05 & 2.52 & 2.09 & 0.314 \\
\hline
\end{tabular}

In contrast, serum $\mathrm{Mg}$ concentrations were decreased in cows treated with cholecalciferol (Figure 1C). No difference was observed between cows treated once and cows treated twice with cholecalciferol. Evaluating the prevalence of hypocalcemia in 115 German dairy herds, we also observed a negative association between serum $\mathrm{Ca}$ and $\mathrm{Mg}$ concentrations. This finding seems to be contradictory, as presence of $\mathrm{Mg}$ is crucial to the $\mathrm{PTH}$ receptor function and therefore maintenance of Ca homeostasis (Goff, 2014b). However, PTH also leads to an increased reabsorption of $\mathrm{Mg}$ from the urine, leading to increased serum $\mathrm{Mg}$ levels (Goff, 2008). One might speculate that, in cows treated with cholecalciferol, PTH secretion was decreased, as serum Ca concentrations were substantially higher than in control cows.
This might have led to lower serum Mg concentrations in treated cows.

In cows treated with $12 \times 10^{6}$ IU of cholecalciferol and cows reinjected with a second dose of $10 \times 10^{6} \mathrm{IU}$ of cholecalciferol, serum 25-hydroxycholecalciferol was significantly increased on d 1, 5, and 10 after calving (Figure 2). This finding is in agreement with Littledike and Horst (1982), who found a 4-fold increase of mean plasma 25-hydroxycholecalciferol concentrations on d 1 after calving in cows treated with cholecalciferol. In the liver, cholecalciferol is converted to 25-hydroxycholecalciferol (Horst et al., 1994, 2003). As described by Goff (2014b), levels of 25-hydroxycholecalciferol increase substantially when high amounts of cholecalciferol are administered. This results in vitamin D receptor bind-

Table 3. Final multivariable logistic regression model evaluating the effect of prepartum injection with cholecalciferol on the probability of metritis ${ }^{1}$

\begin{tabular}{|c|c|c|c|c|c|c|}
\hline \multirow[b]{2}{*}{ Variable } & \multirow[b]{2}{*}{ Estimate } & \multirow[b]{2}{*}{ SE } & \multicolumn{2}{|c|}{$95 \%$ CI } & \multirow[b]{2}{*}{ Odds ratio } & \multirow[b]{2}{*}{$P$-value } \\
\hline & & & Lower CI & Upper CI & & \\
\hline Intercept & -2.01 & 0.04 & -2.13 & -1.89 & 0.13 & $<0.001$ \\
\hline \multicolumn{7}{|l|}{ Treatment } \\
\hline Control & Referent & & & & & \\
\hline Treatment $^{2}$ & 0.86 & 0.05 & 0.70 & 1.01 & 2.35 & $<0.001$ \\
\hline Second treatment ${ }^{3}$ & 0.60 & 0.07 & 0.38 & 0.81 & 1.82 & 0.003 \\
\hline \multicolumn{7}{|l|}{ Calving ease ${ }^{4}$} \\
\hline 1 & Referent & & & & & \\
\hline 2 & 1.11 & 0.06 & 0.94 & 1.28 & 3.03 & $<0.001$ \\
\hline 3 & 1.05 & 0.11 & 0.70 & 1.39 & 2.85 & 0.002 \\
\hline
\end{tabular}

${ }^{1}$ Vaginal discharge was evaluated on $\mathrm{d} 7$ after calving using a Metricheck device (Simcro). Cows with a vaginal discharge score 4 (i.e., red or brown color, watery, foul smelling) were considered as having metritis.

${ }^{2}$ Cows were treated with $12 \times 10^{6} \mathrm{IU}$ of cholecalciferol and were reinjected with $10 \times 10^{6} \mathrm{UI}$ of cholecalciferol if the calf was not delivered within the following $6 \mathrm{~d}$.

${ }^{3}$ Cows were reinjected with $10 \times 10^{6} \mathrm{IU}$ of cholecalciferol if they did not deliver the calf within $6 \mathrm{~d}$ after the first treatment.

${ }^{4}$ Calving ease was defined as: 1 = unassisted calving; 2 = calving assisted by 1 person; $3=$ calving assisted by more than 1 person. 
ing and activation, comparable to the mode of action of 1,25-dihydroxycholecalciferol (Tanaka and Deluca, 1971), which may explain the considerable increase of serum $\mathrm{Ca}$ concentrations in the present study. In contrast to 25-hydroxycholecalciferol, the binding affinity of 1,25-dihydroxycholecalciferol is 150 times more effective. Therefore, high amounts of 25-hydroxycholecalciferol are needed to activate the vitamin D receptor (Brumbaugh and Haussler, 1973). The reference range for 25-hydroxycholecalciferol is between 50 and $150 \mathrm{nmol} / \mathrm{L}$ (Horst and Littledike 1982; Horst et al., 1994; Fairweather et al., 2013). Mean 25-hydroxycholecalciferol concentration of cows injected once with $12 \times 10^{6}$ IU of cholecalciferol was above this reference range beyond 10 DIM, suggesting that a reinjection of cows after $1 \mathrm{wk}$ is not necessary. To the authors' knowledge no studies in the recent past have evaluated the parental application of cholecalciferol in cows fed a negative DCAD diet prepartum. Regarding injectable forms of vitamin $\mathrm{D}$, recent studies have focused on the biologically active form of 1,25-dihydroxycholecalciferol (Vieira-Neto et al., 2017b, 2021). Unfortunately, the half-life of 1,25-dihydroxycholecalciferol is short, and thus the optimal time for application is hard to identify, as prediction of calving is challenging (Wilkens et al., 2020). To overcome this challenge, Vieira-Neto et al. (2017b) treated cows with 1,25-dihydroxycholecalciferol within $6 \mathrm{~h}$ after calving. Additionally, these cows were fed a negative DCAD diet $(-123 \mathrm{mEq} / \mathrm{kg})$ starting at d 255 of gestation. Plasma Ca concentrations increased within $24 \mathrm{~h}$ after calving and returned to baseline on 5 DIM. It has been shown previously that 1,25-dihydroxycholecalciferol inhibits PTH secretion (Chertow et al., 1980). In the study by Vieira-Neto et al. (2017b), injection of 1,25-dihydroxycholecalciferol also had a negative effect on PTH secretion. In the group of treated cows, PTH was significantly lower on 1 and 3 after calving. Plasma Ca concentrations were in turn reduced from 9 to 15 DIM, compared with control cows. That group of authors also replicated the positive effect of 1,25-dihydroxycholecalciferol injection on plasma $\mathrm{Ca}$ levels in a larger number of cows (Vieira-Neto et al., 2021). However, beneficial effects on health in the subsequent lactation were observed only in overconditioned cows.

In the present study, serum BHB and serum NEFA concentrations on $\mathrm{d} 1,5$, and 10 were not affected by treatment with cholecalciferol (Figure $3 \mathrm{~A}$ and $\mathrm{B}$ ). Apart from parenteral application of 1,25-dihydroxycholecalciferol, recent studies have focused on feeding of 25-hydroxycholecalciferol in combination with a negative DCAD diet (Wilkens et al., 2012; Weiss et al., 2015; Martinez et al., 2018a,b; Rodney et al., 2018; Poindexter et al., 2020). Martinez et al. (2018a) evaluated the effect of a negative DCAD diet prepartum supplemented with 25-hydroxycholecalciferol on health and performance in subsequent lactation. In their study cows were fed 4 different prepartum diets, arranged as a $2 \times 2$ factorial design with 2 different DCAD levels $(+130$ vs. $-130 \mathrm{mEq} / \mathrm{kg})$ and 2 different vitamin D supplements (cholecalciferol vs. 25-hydroxycholecalciferol). In the 2 groups fed a negative DCAD diet, clinical and subclinical hypocalcemia were efficiently reduced. The source of vitamin D, however, did not affect Ca concentrations. Furthermore, the effect of treatment on ketosis within the first 30 DIM was evaluated. Although level of DCAD did not affect the incidence of ketosis, feeding of 25-hydroxycholecalciferol in the close-up group tended to increase the percentage of cows with ketosis. Because cows fed 25-hydroxycholecalciferol had a greater milk production but no difference in caloric intake, the authors speculated that the negative energy balance caused a higher incidence of cows with ketosis. Martinez et al. (2016) also observed elevated NEFA levels, in cows with increased calcium concentrations following oral calcium supplementation. The reason, however, remains unclear.

On d 5 after calving, cows treated once with $12 \times$ $10^{6} \mathrm{IU}$ of cholecalciferol had a $0.43 \mathrm{~g} / \mathrm{L}$ increase in serum haptoglobin concentration (Figure 3C). One might speculate that maintaining eucalcemia in early lactation during an immune challenge appeared to intensify inflammation, as has been shown recently by Horst et al. (2020). The specific product characteristics of the cholecalciferol product used in this study describe that in some cases the product can induce allergic hypersensitivity reactions. One might speculate that the increase in haptoglobin concentration is due to a local reaction at the site of cholecalciferol injection. In this case, however, it remains unclear why serum haptoglobin concentrations were not elevated on d 1 after calving and why cows that were reinjected with a second dose of cholecalciferol did not have even more elevated serum haptoglobin concentrations. Signs of toxicity in cows treated with $15 \times 10^{6}$ IU of cholecalciferol 1 mo before calving and $2.5 \times 10^{6} \mathrm{IU} 1$ wk later were described by Littledike and Horst (1982). Clinical manifestation of vitamin D toxicity is mediated by constant hypercalcemia (Vieth, 1990). In the study by Littledike and Horst (1982) 10 out of 17 treated animals died, with 8 cows showing clinical signs of vitamin D toxicity, such as inappetence, polypnea with pronounced expiration, stiffness of joints, and recumbency. Cows enrolled in the earlier study were Jersey cows, most probably weighing 300 to $400 \mathrm{~kg}$ less than the Holstein Friesian cows enrolled in this study. Moreover, the cows in the study by Littledike and Horst were not lactating during the month following the first injection, leading to a substantially lower calcium demand compared with 
cows in the present study. Whether the increased haptoglobin concentrations on d 5 presented herein were caused by toxic effects of cholecalciferol remains unclear, especially as cows reinjected with $10 \times 10^{6} \mathrm{IU}$ of cholecalciferol had fewer signs of detrimental effects on production and health in early lactation. Moreover, the number of cows that died did not differ between control and treatment groups (23/188 for control vs. 18/187 for treated cows). It has to be emphasized, however, that the injected dose of $12 \times 10^{6} \mathrm{IU}$ of cholecalciferol is extremely high. The NRC (2001) recommends an oral daily uptake of $30 \mathrm{IU} / \mathrm{kg}$ of $\mathrm{BW}$ for an adult dairy cow. Taking $800 \mathrm{~kg}$ of BW as an average weight for a Holstein Friesian close-up cow, the cow should receive $24,000 \mathrm{IU}$ of cholecalciferol via feed. The injection of $12 \times 10^{6}$ IU of cholecalciferol exceeds the NRC recommendation by 500 times. As shown in Figure 4, cows in the fourth lactation or greater had a significant increase in rectal temperature on d 2 compared with control cows when they were treated twice with cholecalciferol. In addition, our data show that treated cows had a greater risk for reproductive diseases in early lactation. Cows that were treated once with cholecalciferol before calving had a higher risk of incurring RP (Table 2), and both treatment groups had a higher risk for metritis (Table 3). As part of a counter-regulation induced by high levels of 25-hydroxycholecalciferol, expression of vitamin D 24-hydroxylase (CYP24A1), an enzyme that converts 25-hydroxycholeclaciferol to 24,25-dihydroxycholecalcieferol, is upregulated (Merriman et al., 2018). Shan et al. (1996) demonstrated that 24,25-dihydroxyvitmin D inhibited voltage-dependent calcium channels in smooth muscles. Furthermore, Levene and Lawson (1977) demonstrated toxic effects of different vitamin D metabolites, including 25-hydroxycholecalciferol, on fibroblasts and endothelial cells. Because we did not measure the concentration of these vitamin D metabolites, we can only speculate that they might have been involved in the development of the higher risk of $\mathrm{RP}$ and metritis. In the study by Vieira-Neto et al. (2021), injection of 1,25-dihydroxycholecalciferol within $6 \mathrm{~h}$ after calving was, however, associated with a reduced incidence of RP and metritis in overconditioned cows. Martinez et al. (2018a) found a significant decrease in the incidence of RP and metritis in cows fed with 25-hydroxycholecalciferol but not in cows fed with cholecalciferol. Apart from the treatment effect, one might also speculate that cows treated once with cholecalciferol had a greater risk for RP due to their shorter GL (Vieira-Neto et al., 2017a). However, this is biased due to the study design, as cows with a longer GL received an additional injection of cholecalciferol.

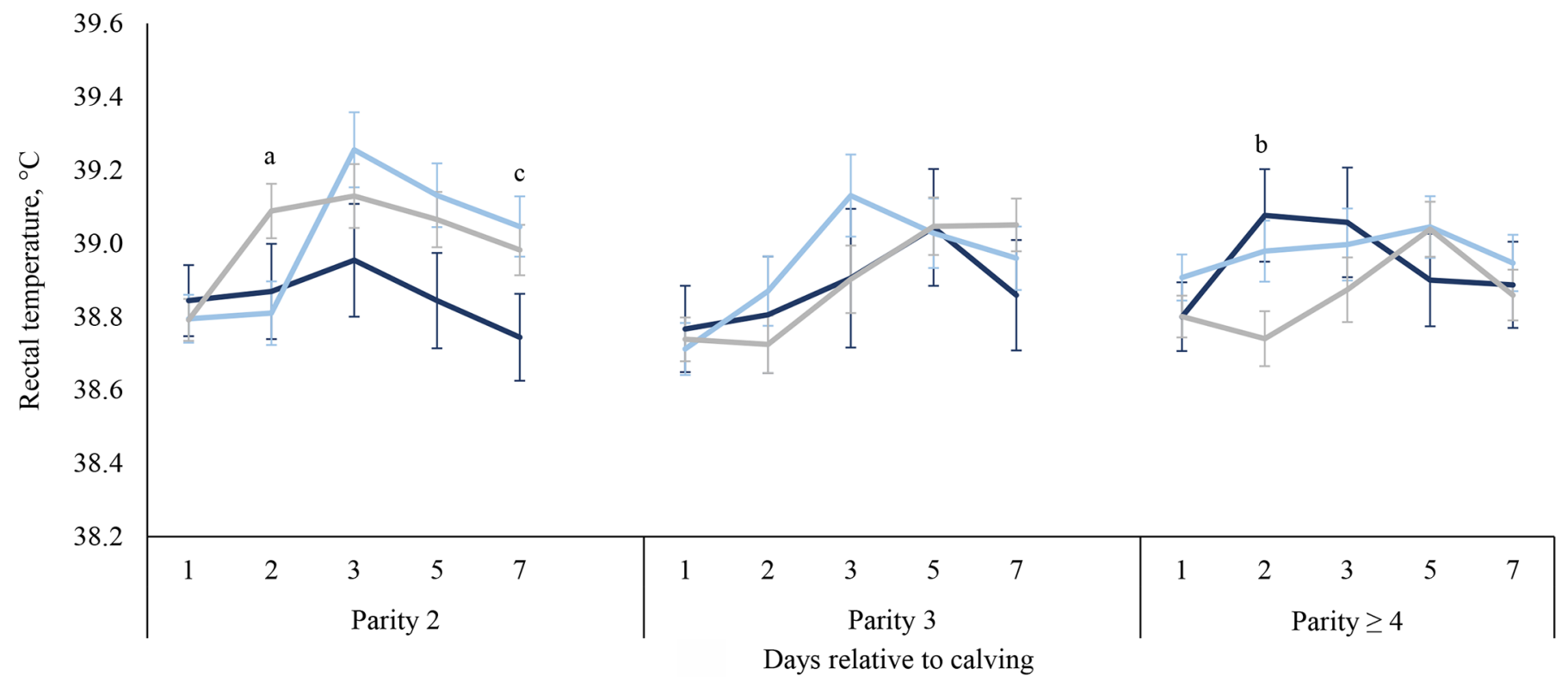

Figure 4. Effect of treatment with $12 \times 10^{6} \mathrm{IU}$ of cholecalciferol $5 \mathrm{~d}$ before expected parturition on rectal temperature $\left({ }^{\circ} \mathrm{C}\right)$ in multiparous dairy cows $(\mathrm{n}=375)$ using least square estimates (mean \pm SEM) from repeated measure ANOVA. Cows were reinjected with $10 \times 10^{6}$ IU of cholecalciferol if they did not deliver the calf within $6 \mathrm{~d}$ after the first treatment. Cows treated once with cholecalciferol are displayed in light blue $(\mathrm{n}=133)$, cows treated twice with cholecalciferol are displayed in black $(\mathrm{n}=54)$, and cows of the control group $(\mathrm{n}=188)$ are displayed in gray. Time $(P<0.001)$ and calving ease $(P=0.001)$ had a significant effect on rectal temperature. A tendency was observed for treatment $(P$ $=0.069)$, time by treatment by parity $(P=0.064)$, and sex of the calf to affect rectal temperature $(P=0.066)$. Pairwise comparisons among groups with Bonferroni's corrected $P<0.05$ are marked with the following letters: a, control vs. single injection of cholecalciferol; b, control vs. 2 injections of cholecalciferol; c, single injection of cholecalciferol vs. 2 injections of cholecalciferol. 


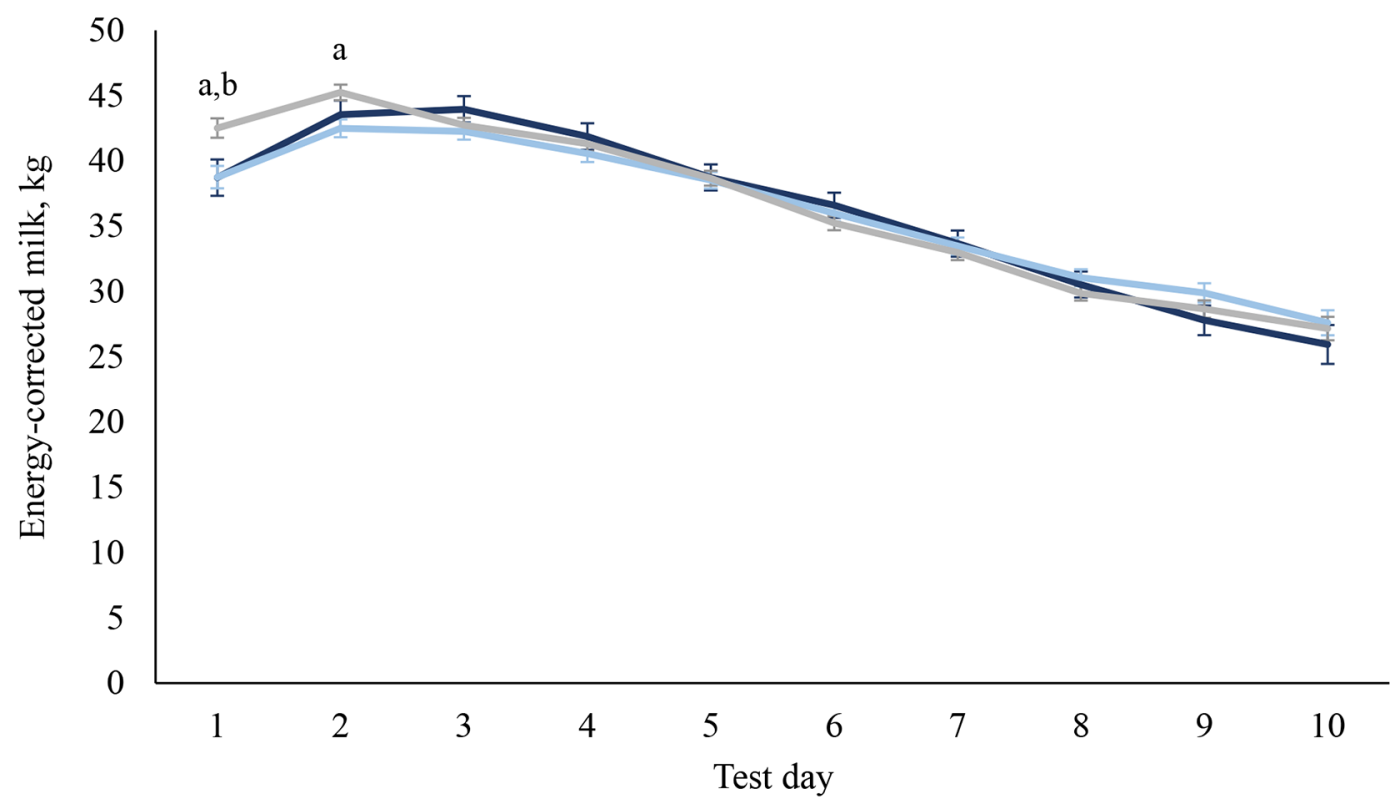

Figure 5. Effect of treatment with $12 \times 10^{6} \mathrm{IU}$ f cholecalciferol $5 \mathrm{~d}$ before expected parturition on ECM (kg of ECM/d) in multiparous dairy cows $(\mathrm{n}=375)$ using least square estimates $($ mean $\pm \mathrm{SEM})$ from repeated measure ANOVA. Cows were reinjected with $10 \times 10^{6}$ IU of cholecalciferol if they did not deliver the calf within $6 \mathrm{~d}$ after the first treatment. Cows treated with cholecalciferol once are displayed in light blue $(\mathrm{n}=133)$, cows treated with cholecalciferol twice are displayed in black $(\mathrm{n}=54)$, and cows of the control group $(\mathrm{n}=188)$ are displayed in gray. Parity $(P<0.001)$, time $(P<0.001)$, time by treatment $(P=0.007)$, 305-d milk yield of previous lactation $(P<0.001)$, and calving ease $(P=0.008)$ had a significant effect on milk yield in subsequent lactation. Pairwise comparisons among groups with Bonferroni's corrected $P<$ 0.05 are marked with the following letters: a, control vs. single injection of cholecalciferol; b, control vs. 2 injections of cholecalciferol.

Cows treated with $12 \times 10^{6}$ IU of cholecalciferol produced less milk on the first and second test days compared with cows in the control group. In contrast, cows that were reinjected with $10 \times 10^{6} \mathrm{IU}$ of cholecalciferol produced less milk compared with control cows only on the first test day (Figure 5). Studies evaluating the effect of feeding 25-hydroxycholecalciferol or cholecalciferol in combination with 2 different levels of prepartum DCAD diet $(-130$ vs. $+130 \mathrm{mEq} / \mathrm{kg})$ have found a positive effect of 25-hydroxycholecalciferol on milk production. Two studies also showed a positive effect on colostrum production in cows supplemented with 25-hydroxycholecalciferol (Martinez et al., 2018b; Rodney et al., 2018). Throughout the observation period (until 49 DIM), cows supplemented with 25-hydroxycholecalciferol produced $3.70 \mathrm{~kg} / \mathrm{d}$ more milk than cows fed with cholecalciferol (Martinez et al., 2018b).

In the present study, time to pregnancy was increased in cows with a single injection of $12 \times 10^{6}$ IU of cholecalciferol before calving (Figure 6). Cows treated once had a 3-d reduction in GL, greater risk for RP and metritis, and higher serum haptoglobin concentrations on $\mathrm{d} 5$. The detrimental effect on reproductive health in early lactation might explain the delay in time to pregnancy for cows treated with cholecalciferol. In compari- son, feeding cholecalciferol or 25-hydroxycholecalciferol led to a 19-d reduction in days open (Martinez et al., 2018a).

Despite the negative influence of treatment on milk yield and reproductive performance, we did not observe a treatment effect on culling within $300 \mathrm{~d}$. This is similar to a previous study mentioned, which found an association neither between feeding of cholecalciferol and culling risk during the following $305 \mathrm{~d}$, nor between feeding 25-hydroxycholecalciferol and culling risk (Martinez et al., 2018a).

After a preliminary statistical analysis at d 90 of the study, an unacceptable incidence of diseases and reduction of milk yield were observed in association with the cholecalciferol treatment. Deviating from the original study protocol with an inclusion of 1,200 cows, the study was aborted to prevent further losses to the dairy farm and to avoid animal welfare issues. In human medicine trials, occurrence of early evidence of an inferior treatment outcome with harm to the study subject is commonly accepted as reason for premature termination of the trial (Bassler et al., 2010). A similar approach has been described for a study investigating the effect of a negative DCAD diet in the close-up group on postpartum health on a commercial dairy farm (Serrenho et al., 2021a). 


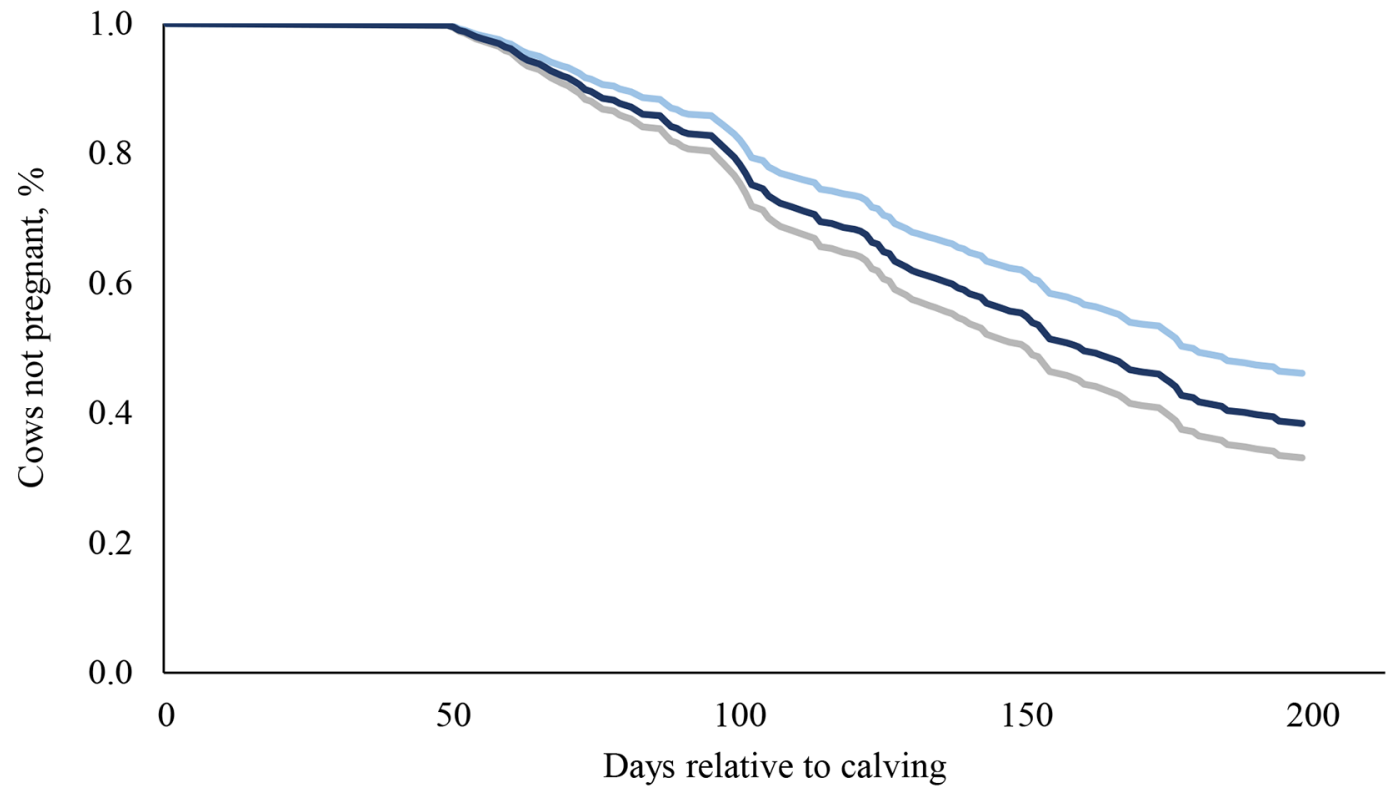

Figure 6. Kaplan-Meier survival analysis illustrating the association of cholecalciferol treatment 5 d before calving with time to pregnancy within 200 DIM in 375 Holstein cows. Cows were reinjected with $10 \times 10^{6} \mathrm{IU}$ of cholecalciferol if they did not deliver the calf within $6 \mathrm{~d}$ after the first treatment. Cows treated once with cholecalciferol are displayed in light blue $(\mathrm{n}=133)$, cows treated twice with cholecalciferol are displayed in black, and cows of the control group $(\mathrm{n}=188)$ are displayed in gray. Cows treated once with $12 \times 10^{6}$ IU of cholecalciferol had a significantly reduced hazard of pregnancy compared with control cows (hazard ratio $=0.70 ; 95 \%$ CI: $0.52-0.95 ; P=0.020$ ). Median days to pregnancy were 146, 154, and 180 for control cows, cows treated once, and cows treated twice with cholecalciferol, respectively. Furthermore, parity $(P<0.001)$ remained significant in the final model.

Cows in the control group were not treated with a placebo. Furthermore, we were not able to quantify blood cholecalciferol concentrations. Therefore, it is impossible to differentiate whether detrimental effects were provoked by the process of injection, cholecalciferol toxicity, or an adjuvant substance.

\section{CONCLUSIONS}

The present study shows that prepartum injection with $12 \times 10^{6}$ IU of cholecalciferol had a pronounced effect on mineral metabolism and on 25-hydroxycholecalciferol levels. Although the marked increase in serum $\mathrm{Ca}$ was promising to reduce the portion of cows with subclinical hypocalcemia, injection of $12 \times 10^{6} \mathrm{IU}$ of cholecalciferol had detrimental effects on subsequent health, milk yield, and reproductive performance. Further research is warranted to determine whether the dosage of cholecalciferol used $\left(12 \times 10^{6} \mathrm{IU}\right.$ of cholecalciferol and a reinjection if the calf was not delivered within $6 \mathrm{~d}$ following the first treatment) might be the reason for negative effects on serum haptoglobin concentration, ECM, and time to pregnancy, and to evaluate whether the present results can be replicated on other farms.

\section{ACKNOWLEDGMENTS}

The study was funded by the Ruminant and Swine Clinic, University of Berlin (Germany). The authors are grateful to the owners and employees of the collaborating dairy farm for granting access to their facilities, cows, and herd records, and for their kind support. The authors have not stated any conflicts of interest.

\section{REFERENCES}

Bassler, D., M. Briel, V. M. Montori, and M. Lane. 2010. Stopping randomized trials early for benefit and estimation of treatment effects. JAMA 303:1180-1187. https://doi.org/10.1001/jama.2010 .310 .

Brumbaugh, P. F., and M. R. Haussler. 1973. la,25-dihydroxyvitamin $\mathrm{D}_{3}$ receptor: Competitive binding of vitamin D analogs. Life Sci. 13:1737-1746. https://doi.org/10.1016/0024-3205(73)90120-3.

Caixeta, L. S., P. A. Ospina, M. B. Capel, and D. V. Nydam. 2017. Association between subclinical hypocalcemia in the first 3 days of lactation and reproductive performance of dairy cows. Theriogenology 94:1-7. https://doi.org/10.1016/j.theriogenology.2017.01 .039 .

Chertow, B. S., G. R. Baker, H. L. Henry, and A. W. Norman. 1980. Effects of vitamin D metabolites on bovine parathyroid hormone release in vitro. Am. J. Physiol. Endocrinol. Metab. 238:E384E388. https://doi.org/10.1152/ajpendo.1980.238.4.E384.

Clinical and Laboratory Standards Institute (CLSI). 2012. Evaluation of Detection Capability for Clinical Laboratory Measurement Procedures: Approved Guideline. 2nd ed. CLSI Document EP17-A2. Clinical and Laboratory Standards Institute. 
Constable, P. D., K. W. Hinchcliff, S. H. Done, and W. Grünberg. 2016. Veterinary Medicine: A Textbook of the Diseases of Cattle, Horses, Sheep, Pigs and Goats. Elsevier Health Sciences.

Dohoo, I. R., S. W. Martin, and H. Stryhn. 2009. Veterinary Epidemiologic Research. 2nd ed. VER Inc.

Fairweather, A. A. C., C. T. Eason, P. A. Elder, C. M. F. Eason, and D. Arthur. 2013. Reference concentrations of cholecalciferol in animals: A basis for establishing non-target exposure. N. Z. J. Zool. 40:280-289. https://doi.org/10.1080/03014223.2013.772527.

Goff, J. P. 2000. Pathophysiology of calcium and phosphorus disorders. Vet. Clin. North Am. Food Anim. Pract. 16:319-337. https:/ /doi.org/10.1016/S0749-0720(15)30108-0.

Goff, J. P. 2008. The monitoring, prevention, and treatment of milk fever and subclinical hypocalcemia in dairy cows. Vet. J. 176:50-57. https://doi.org/10.1016/j.tvjl.2007.12.020.

Goff, J. P. 2014b. Calcium and magnesium disorders. Vet. Clin. North Am. Food Anim. Pract. 30:359-381. https://doi.org/10.1016/j .cvfa.2014.04.003.

Goff, J. P., A. Liesegang, and R. L. Horst. 2014a. Diet-induced pseudohypoparathyroidism: A hypocalcemia and milk fever risk factor. J. Dairy Sci. 97:1520-1528. https://doi.org/10.3168/jds.2013-7467.

Gürtler, H., H. Seidel, and E. Liebaug. 1977. Prophylaxe der Gebärparese der Milchkuh durch Verabreichen hoher Dosen Vitamin D3 [Prevention against milk fever in dairy cows by administering high doses of Vitamin D3]. Monatsh. Veterinarmed. 32:664-668.

Hodnik, J. J., J. Ježek, and J. Starič. 2020. A review of vitamin D and its importance to the health of dairy cattle. J. Dairy Res. 87(Suppl. 1):84-87. https://doi.org/10.1017/S0022029920000424.

Horst, R. L., J. P. Goff, and T. A. Reinhardt. 1994. Calcium and vitamin D metabolism in the dairy cow. J. Dairy Sci. 77:1936-1951. https://doi.org/10.3168/jds.S0022-0302(94)77140-X.

Horst, R. L., J. P. Goff, and T. A. Reinhardt. 2003. Role of vitamin D in calcium homeostasis and its use in prevention of bovine periparturient paresis. Acta Vet. Scand. Suppl. 97:35-50.

Horst, R. L., and E. T. Littledike. 1982. Comparison of plasma concentrations of vitamin D and its metabolites in young and aged domestic animals. Comp. Biochem. Physiol. B 73:485-489. https:/ /doi.org/10.1016/0305-0491(82)90064-5.

Horst, E. A., E. J. Mayorga, M. Al-Qaisi, M. A. Abeyta, S. L. Portner, C. S. McCarthy, B. M. Goetz, S. K. Kvidera, and L. H. Baumgard. 2020. Effects of maintaining eucalcemia following immunoactivation in lactating Holstein dairy cows. J. Dairy Sci. 103:7472-7486. https://doi.org/10.3168/jds.2020-18268.

Julien, W. E., H. R. Conrad, J. W. Hibbs, and W. L. Crist. 1977. Milk fever in dairy cows. VIII. Effect of injected vitamin $\mathrm{D}_{3}$ and calcium and phosphorus intake on incidence. 60:431-436. https://doi.org/ 10.3168/jds.S0022-0302(77)83883-6.

Kimura, K., T. A. Reinhardt, and J. P. Goff. 2006. Parturition and hypocalcemia blunts calcium signals in immune cells of dairy cattle. J. Dairy Sci. 89:2588-2595. https://doi.org/10.3168/jds.S0022 $-0302(06) 72335-9$.

Levene, C. I., and D. E. M. Lawson. 1977. A possible effect of vitamin D metabolites on cell adhesion. Cell Biol. Int. Rep. 1:93-97. https: //doi.org/10.1016/0309-1651(77)90015-7.

Littledike, E. T., and R. L. Horst. 1982. Vitamin $\mathrm{D}_{3}$ toxicity in dairy cows. J. Dairy Sci. 65:749-759. https://doi.org/10.3168/jds.S0022 $-0302(82) 82263-7$.

Martín-Tereso, J., and H. Martens. 2014. Calcium and magnesium physiology and nutrition in relation to the prevention of milk fever and tetany (dietary management of macrominerals in preventing disease). Vet. Clin. North Am. Food Anim. Pract. 30:643-670. https://doi.org/10.1016/j.cvfa.2014.07.007.

Martinez, N., C. A. Risco, F. S. Lima, R. S. Bisinotto, L. F. Greco, E. S. Ribeiro, F. Maunsell, K. Galvão, and J. E. P. Santos. 2012. Evaluation of peripartal calcium status, energetic profile, and neutrophil function in dairy cows at low or high risk of developing uterine disease. J. Dairy Sci. 95:7158-7172. https://doi.org/10 $.3168 /$ jds.2012-5812.

Martinez, N., R. M. Rodney, E. Block, L. L. Hernandez, C. D. Nelson, I. J. Lean, and J. E. P. Santos. 2018a. Effects of prepartum dietary cation-anion difference and source of vitamin $\mathrm{D}$ in dairy cows:
Health and reproductive responses. J. Dairy Sci. 101:2563-2578. https://doi.org/10.3168/jds.2017-13740.

Martinez, N., R. M. Rodney, E. Block, L. L. Hernandez, C. D. Nelson, I. J. Lean, and J. E. P. Santos. 2018b. Effects of prepartum dietary cation-anion difference and source of vitamin D in dairy cows: Lactation performance and energy metabolism. J. Dairy Sci. 101:2544-2562. https://doi.org/10.3168/jds.2017-13739.

Martinez, N., L. D. P. Sinedino, R. S. Bisinotto, R. Daetz, C. A. Risco, K. N. Galvão, W. W. Thatcher, and J. E. P. Santos. 2016. Effects of oral calcium supplementation on productive and reproductive performance in Holstein cows. J. Dairy Sci. 99:8417-8430. https:/ /doi.org/10.3168/jds.2015-10529.

McArt, J. A. A., and R. C. Neves. 2020. Association of transient, persistent, or delayed subclinical hypocalcemia with early lactation disease, removal, and milk yield in Holstein cows. J. Dairy Sci. 103:690-701. https://doi.org/10.3168/jds.2019-17191.

Merriman, K. E., J. L. Powell, J. E. P. Santos, and C. D. Nelson. 2018. Intramammary 25-hydroxyvitamin $\mathrm{D}_{3}$ treatment modulates innate immune responses to endotoxin-induced mastitis. J. Dairy Sci. 101:7593-7607. https://doi.org/10.3168/jds.2017-14143.

Neves, R. C., B. M. Leno, K. D. Bach, and J. A. A. McArt. 2018. Epidemiology of subclinical hypocalcemia in early-lactation Holstein dairy cows: The temporal associations of plasma calcium concentration in the first 4 days in milk with disease and milk production. J. Dairy Sci. 101:9321-9331. https://doi.org/10.3168/ jds.2018-14587.

NRC. 2001. Nutrient Requirements of Dairy Cattle. 7th ed. Natl. Acad. Press.

Oehlschlaeger, V., M. Wilkens, B. Schroeder, S. Daenicke, and G. Breves. 2014. Effects of 25-hydroxyvitamin $\mathrm{D}_{3}$ on localisation and extent of gastrointestinal calcium absorption in dairy cattle. Anim. Prod. Sci. 54:1394. https://doi.org/10.1071/AN14344.

Poindexter, M. B., M. F. Kweh, R. Zimpel, J. Zuniga, C. Lopera, M. G. Zenobi, Y. Jiang, M. Engstrom, P. Celi, J. E. P. Santos, and C. D. Nelson. 2020. Feeding supplemental 25-hydroxyvitamin $\mathrm{D}_{3}$ increases serum mineral concentrations and alters mammary immunity of lactating dairy cows. J. Dairy Sci. 103:805-822. https:/ /doi.org/10.3168/jds.2019-16999.

Roberts, T., N. Chapinal, S. J. Leblanc, D. F. Kelton, J. Dubuc, and T. F. Duffield. 2012. Metabolic parameters in transition cows as indicators for early-lactation culling risk. J. Dairy Sci. 95:30573063. https://doi.org/10.3168/jds.2011-4937.

Rodney, R. M., N. Martinez, E. Block, L. L. Hernandez, P. Celi, C. D. Nelson, J. E. P. Santos, and I. L. Lean. 2018. Effects of prepartum dietary cation-anion difference and source of vitamin D in dairy cows: Vitamin D, mineral, and bone metabolism. J. Dairy Sci. 101:2519-2543. https://doi.org/10.3168/jds.2017-13737.

Seely, C. R., B. M. Leno, A. L. Kerwin, T. R. Overton, and J. A. A. McArt. 2021. Association of subclinical hypocalcemia dynamics with dry matter intake, milk yield, and blood minerals during the periparturient period. J. Dairy Sci. 104:4692-4702. https://doi .org/10.3168/jds.2020-19344.

Seifi, H. A., S. J. Leblanc, K. E. Leslie, and T. F. Duffield. 2011. Metabolic predictors of post-partum disease and culling risk in dairy cattle. Vet. J. 188:216-220. https://doi.org/10.1016/j.tvjl 2010.04.007.

Serrenho, R. C., T. C. Bruinjé, E. I. Morrison, T. J. DeVries, T. F. Duffield, and S. J. Leblanc. 2021a. Controlled trial of the effect of negative dietary cation-anion difference on postpartum health of dairy cows. J. Dairy Sci. 104:6929-6943. https://doi.org/10.3168/ jds.2020-19389.

Serrenho, R. C., T. J. DeVries, T. F. Duffield, and S. J. Leblanc. 2021b. Graduate Student Literature Review: What do we know about the effects of clinical and subclinical hypocalcemia on health and performance of dairy cows? J. Dairy Sci. 104:6304-6326. https: //doi.org/10.3168/jds.2020-19371.

Shan, J. J., B. Li, N. Taniguchi, and P. K. T. Pang. 1996. Inhibition of membrane L-type calcium channel activity and intracellular calcium concentration by $24 \mathrm{R}, 25$-dihydroxyvitamin $\mathrm{D}_{3}$ in vascular smooth muscle. Steroids 61:657-663. https://doi.org/10.1016/ S0039-128X(96)00186-9. 
Sheldon, I. M., G. S. Lewis, S. LeBlanc, and R. O. Gilbert. 2006. Defining postpartum uterine disease in cattle. Theriogenology 65:1516-1530. https://doi.org/10.1016/j.theriogenology.2005.08 .021 .

Tanaka, Y., and H. F. Deluca. 1971. Bone mineral mobilization activity of 1,25-dihydroxycholecalciferol, a metabolite of vitamin D. Arch. Biochem. Biophys. 146:574-578. https://doi.org/10.1016/ 0003-9861(71)90163-9.

Taylor, M. S., K. F. Knowlton, M. L. McGilliard, W. M. Seymour, and J. H. Herbein. 2008. Blood mineral, hormone, and osteocalcin responses of multiparous Jersey cows to an oral dose of 25-hydroxyvitamin $\mathrm{D}_{3}$ or vitamin $\mathrm{D}_{3}$ before parturition. J. Dairy Sci. 91:2408-2416. https://doi.org/10.3168/jds.2007-0750.

Urton, G., M. A. G. von Keyserlingk, and D. M. Weary. 2005. Feeding behavior identifies dairy cows at risk for metritis. J. Dairy Sci. 88:2843-2849. https://doi.org/10.3168/jds.S0022-0302(05)72965 -9 .

Venjakob, P. L., S. Borchardt, and W. Heuwieser. 2017. Hypocalcemia-cow-level prevalence and preventive strategies in German dairy herds. J. Dairy Sci. 100:9258-9266. https://doi.org/10.3168/ jds.2016-12494.

Venjakob, P. L., L. Pieper, W. Heuwieser, and S. Borchardt. 2018. Association of postpartum hypocalcemia with early-lactation milk yield, reproductive performance, and culling in dairy cows. J. Dairy Sci. 101:9396-9405. https://doi.org/10.3168/jds.2017-14202.

Venjakob, P. L., R. Staufenbiel, W. Heuwieser, and S. Borchardt. 2019. Serum calcium dynamics within the first 3 days in milk and the associated risk of acute puerperal metritis. J. Dairy Sci. 102:1142811438. https://doi.org/10.3168/jds.2019-16721.

Vieira-Neto, A., K. N. Galvão, W. W. Thatcher, and J. E. P. Santos. 2017a. Association among gestation length and health, production, and reproduction in Holstein cows and implications for their offspring. J. Dairy Sci. 100:3166-3181. https://doi.org/10.3168/ jds.2016-11867.

Vieira-Neto, A., I. R. P. Lima, F. Lopes Jr., C. Lopera, R. Zimpel, L. D. P. Sinedino, K. C. Jeong, K. Galvão, W. W. Thatcher, C. D. Nelson, and J. E. P. Santos. 2017b. Use of calcitriol to maintain postpartum blood calcium and improve immune function in dairy cows. J. Dairy Sci. 100:5805-5823. https://doi.org/10.3168/ jds.2016-12506.

Vieira-Neto, A., G. Negro, R. Zimpel, M. Poindexter, F. Lopes Jr., W. W. Thatcher, C. D. Nelson, and J. E. P. Santos. 2021. Effects of injectable calcitriol on mineral metabolism and postpartum health and performance in dairy cows. J. Dairy Sci. 104:683-701. https:/ /doi.org/10.3168/jds.2020-18448.

Vieth, R. 1990. The mechanisms of vitamin D toxicity. Bone Miner. 11:267-272. https://doi.org/10.1016/0169-6009(90)90023-9.

Weber, J., J. Prusseit, and R. Staufenbiel. 2021. Effects of calcium supplementation, incomplete milking, and vitamin $\mathrm{D}_{3}$ injection on serum total calcium concentration during the first 24 hours after parturition in dairy cows fed an anionic diet during late gestation. Am. J. Vet. Res. 82:634-643. https://doi.org/10.2460/ajvr 82.8.634.

Weiss, W. P., E. Azem, W. Steinberg, and T. A. Reinhardt. 2015. Effect of feeding 25-hydroxyvitamin $\mathrm{D}_{3}$ with a negative cation-anion difference diet on calcium and vitamin D status of periparturient cows and their calves. J. Dairy Sci. 98:5588-5600. https://doi.org/ $10.3168 /$ jds.2014-9188.

Wilkens, M. R., and A. S. Muscher-Banse. 2020. Review: Regulation of gastrointestinal and renal transport of calcium and phosphorus in ruminants. Animal 14(Suppl. 1):s29-s43. https://doi.org/10.1017/ S1751731119003197.

Wilkens, M. R., C. D. Nelson, L. L. Hernandez, and J. A. A. McArt. 2020. Symposium review: Transition cow calcium homeostasisHealth effects of hypocalcemia and strategies for prevention. J. Dairy Sci. 103:2909-2927. https://doi.org/10.3168/jds.2019-17268.

Wilkens, M. R., I. Oberheide, B. Schröder, E. Azem, W. Steinberg, and G. Breves. 2012. Influence of the combination of 25-hydroxyvitamin $\mathrm{D}_{3}$ and a diet negative in cation-anion difference on peripartal calcium homeostasis of dairy cows. J. Dairy Sci. 95:151-164. https://doi.org/10.3168/jds.2011-4342.

\section{ORCIDS}

P. L. Venjakob ำ https://orcid.org/0000-0001-7541-5508

R. Staufenbiel $\odot$ https://orcid.org/0000-0001-7983-4603

M. R. Wilkens $\odot$ https://orcid.org/0000-0003-1734-5024

C. Weber (ㄴ) https://orcid.org/0000-0003-4858-2188

W. Heuwieser ๑ https://orcid.org/0000-0003-1434-7083

S. Borchardt @ \ttps://orcid.org/0000-0003-3937-5777 